\title{
Propane, n-Butane and i-Butane Stabilization Effects on Methane Gas Hydrates
}

${ }^{\star}$ Callum Smith ${ }^{\text {curtin university }}$

Curtin University, 5 De Laeter Way, Bentley 6102, Perth WA. Australia callum.c.smith@student.curtin.edu.au

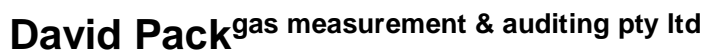

Gas Measurement \& Auditing Pty Ltd, P.O Box 458. Kalamunda 6926, Perth WA. Australia

gasmeasurement@bigpond.com

\author{
Ahmed Barifcani ${ }^{\text {curtin university }}$ \\ Curtin University, 5 De Laeter Way, Bentley 6102, Perth WA. Australia \\ a.barifcani@curtin.edu.au
}




\section{Abstract}

The goal of this work is to analyse the hydrate equilibria of methane + propane, i-butane and $\mathrm{n}$-butane gas mixtures. Experimental hydrate equilibrium data was acquired for various compositions of these components in methane, ranging from $0.5-6.8 \mathrm{~mol} \%$. Applying this information with the Clausius-Clapeyron equation, the extent of hydrate promotion was demonstrated quantitatively by calculating the slope of the equation and the dissociation enthalpy $\left(\Delta H_{d}\right)$. Methane equilibria was found to be most sensitive towards propane and ibutane, where very small concentrations were sufficient to increase the thermodynamic conditions for hydrate equilibrium drastically. The degree of hydrate stabilisation, i.e. transition from sl to sll hydrate, was immediate - there was no detectable composition slightly above $0.0 \mathrm{~mol} \%$ where propane or i-butane did not have a sll hydrate-promoting impact, although one was implied with the aid of Calsep PVTsim calculations. Addition of nbutane to methane was far less sensitive and was deemed inert from $0.0-0.5 \mathrm{~mol} \%$. It was concluded that the sll hydrate was favoured when the $\mathrm{n}$-butane composition exceeded 0.5 $0.75 \mathrm{~mol} \%$. The influence of composition on stability was quantified by determining the gradient of $\Delta H_{d}$ versus mol\% plots for the initial steep region that represents the increasing occupancy of the sll guests. Average gradients of $11.66,26.64$ and $43.50 \mathrm{~kJ} / \mathrm{mol}$.mol\% were determined for $n$-butane, propane and i-butane addition to methane respectively. A hydrateinert range for propane/i-butane (in methane) was suspected according to the perceived inflection point when less $0.5 \mathrm{~mol} \%$, implying the gradient was very low at some minute concentration range starting at $0.0 \mathrm{~mol} \%$. Awareness of these sl to sll transition regions is beneficial to natural gas recovery and processing as a small percentage of these components may remain without being detrimental in terms of promoting the hydrate equilibria.

Keywords: Enthalpy of dissociation; Gas hydrate; Hydrate structure 


\section{Introduction}

This study explores the varying degree of hydrate stabilization offered by propane $\left(C_{3}\right), n$ butane $\left(\mathrm{nC}_{4}\right)$ and $\mathrm{i}$-butane $\left(\mathrm{iC}_{4}\right)$ to hydrates of methane gas $\left(\mathrm{C}_{1}\right)$. This stabilization effect is individually explored with various compositions of the stabilizing gas in binary gas mixtures with $\mathrm{C}_{1}$ between 20 and 160 bar. Experimentally determining the hydrate dissociation temperature for the gas mixtures and comparing them to $\mathrm{C}_{1}$ hydrate dissociation data indicates the extent of stabilization induced by the introduced gas. The hydrate promoting effects of larger gas molecules in natural gas were reported in an earlier study by Hitchon (1974). This effect was also observed in a previous study (Smith, et al., 2016). The study confirmed that $\mathrm{C}_{3}$ and $\mathrm{iC}_{4}+\mathrm{nC}_{4}$ were the greatest contributors of the natural gas hydrocarbons in promoting the equilibrium conditions of natural gas hydrate.

An approximation of the $\mathrm{C}_{3} / \mathrm{iC}_{4} / \mathrm{nC}_{4}$ concentration range in $\mathrm{C}_{1}$ required to form the more stable structure II hydrate is investigated. The intermediate gases, particularly $\mathrm{C}_{3}$, have been shown to cause the formation conditions of $C_{1}$ gas hydrates to shift to higher temperatures and lower pressures, essentially promoting their formation. This has been experimentally demonstrated recently by Schicks and co-workers where sll is the favoured configuration (Schicks, et al., 2006). The large $5^{12} 6^{2}$ cavity of structure I (sl) hydrate is too small to accommodate larger gas molecules, whereas the larger $5^{12} 6^{4}$ cavity present in sll lattices is large enough for a larger molecule, such as $\mathrm{C}_{3}$ or $\mathrm{iC}_{4}$, to stabilize. Potential stabilization of these larger sll cavities in the presence of $C_{1}$ promotes the hydrate equilibrium conditions by way of the formation of sll hydrates. Stabilization of $\mathrm{C}_{1}$ hydrates also manifests upon the addition of $\mathrm{sl}$ hydrate formers. Ethane, for example, is capable of entering the $5^{12} 6^{2}$ cage of sl hydrates according to its van der Waals radius (Lederhos, et al., 1993). Early hydrate equilibrium studies performed by Deaton and Frost (1946) demonstrate the added stability provided by ethane. Similarly, carbon dioxide also provides a stabilizing effect whilst maintaining a sl lattice (Adisasmito, et al., 1991); (Adisasmito \& Sloan, 1992). However, the influence of sll formers are focused on in this study.

Although it has been determined that not all cavities are required to be occupied by a guest (Shin, et al., 2009), particularly the larger cavities, hydrate formation occurs more readily when the large cages are occupied due to thermodynamic stabilization. Due to $\mathrm{C}_{1}$ 's size, it cannot adequately stabilize the $5^{12} 6^{4}$ cage in sll hydrates; a size/cavity ratio of approximately $75 \%$ is required for a stable occupation of a cavity and this ratio is only $66.4 \%$ for $\mathrm{C}_{1}$ (Christiansen \& Sloan, 1994), hence $C_{1}$ prefers the $5^{12}$ cavity. For sll hydrate configurations, 136 water molecules constitute a unit cell where a total of 24 cavities, 16 small $5^{12}$ and 8 
large $5^{12} 6^{4}$ cages, are available for occupation by a guest molecule. For a saturated hydrate phase, this simplifies to a 17:1 molar ratio which is commonly denoted as the hydration number, $\mathrm{n}$. A hydration number of 17 represents complete occupation of all cages, but because of the non-stoichiometric nature of hydrates, a hydration number greater than 17 is more realistic. It therefore cannot be accurately assumed that a hydrate is fully stabilized due to saturation on account of the extent of filling. Extent of filling is dependent on temperature, pressure and guest molecule size (Cady, 1983). This therefore implies that the equilibrium conditions are altered to a varying extent throughout the vapour-liquid-hydrate $\left(V-L_{w}-H\right)$ phase region when a fixed amount of sll promoting gas is introduced to $\mathrm{C}_{1}$. For example, it has been previously determined (Smith et al. 2015) that the change in equilibrium temperature is not fixed throughout the $\mathrm{V}-\mathrm{L}_{\mathrm{w}}-\mathrm{H}$ region, but varies when at different points on the equilibrium phase boundary. This effect is explored by experimenting with various binary $\mathrm{C}_{1}$ gas compositions diluted with $\mathrm{C}_{3}, \mathrm{iC}_{4}$ and in some cases $\mathrm{nC}_{4}$ using a sapphire microcell and comparing these results to pure $\mathrm{C}_{1}$ hydrate equilibrium data. $\mathrm{N}_{2}$ dilution of the sll hydrate forming gases is also investigated to a minor extent.

\section{Methodology}

A hydrate reactor consisting of a PVT cell unit is the primary apparatus used for hydrate synthesis. Other major equipment includes a piston pump and chiller, all of which are integrated within a flow loop (Figure 1). The apparatus is associated with a Clean Gas Technologies Australia (CGTA) laboratory that is especially capable of gas hydrate analysis and $\mathrm{CO}_{2}$ capture. The flow loop utilizes $1 / 4$ inch stainless steel tubing and manual ball valves. Its simplicity makes handling and control of the flow loop a safe and non-demanding process. 


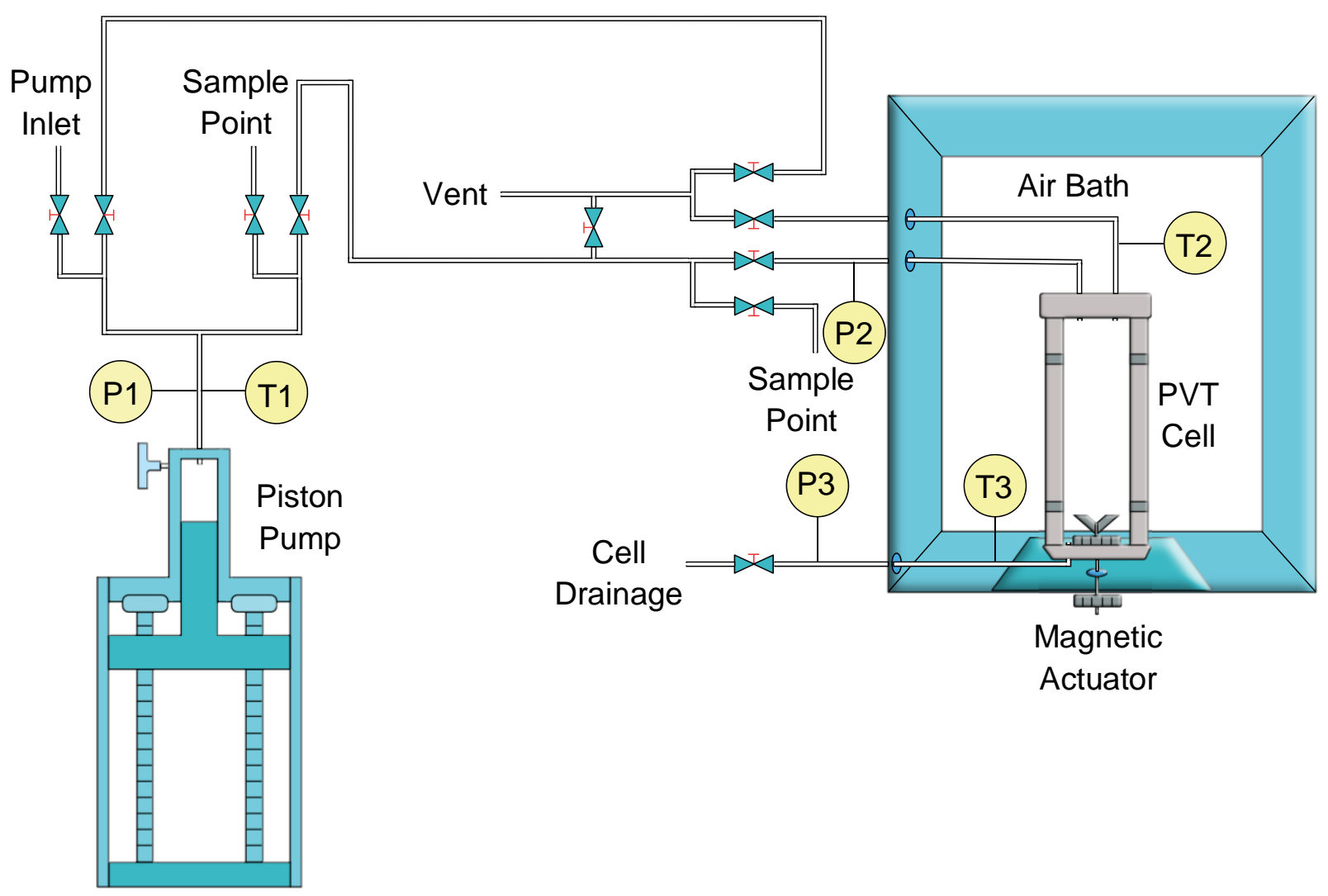

Figure 1 - PVT Cell Flow Loop (Smith, et al., 2015)

The PVT cell is cylindrical and constitutes 1 inch thick glass for enduring pressures up to 500 bar. The volume of the cell is $80 \mathrm{~cm}^{3}$ and $106 \mathrm{~cm}^{3}$ inclusive of internal tubing. Tightly sealed metal palettes at the top and bottom of the cell connect the $1 / 4$ inch tubing to and from the interior, enabling gas/water introduction and drainage respectively. The apparatus can be operated safely to temperatures as low as $-160^{\circ} \mathrm{C}$ allowing for versatile operating conditions. A magnetic actuator for agitation and mixing of the water-hydrate phase is installed and is controlled manually with a dial. The PVT cell is contained in a temperaturecontrolled environment, where heat transfer from outside the containment is minimized with heavy insulation. Access to the interior, or air bath, is allowed by an insulated door, which can be clamped shut for a tight seal and effective temperature control of the PVT cell's contents.

\subsection{Apparatus Application}

Gas pressurization is controlled with a Baldor motion controller, i.e. a proportional-integralderivative (PID) controller. Pressure set points are manually input into Mint Workbench, the controller's associated software. Monitoring of pressure is performed at several points of interest, but the pressure set point for hydrate reactions corresponds to the P2 position of the flow loop where the pressure reading is displayed on an overhead digital display. The 
associated pressure expanded uncertainty is $U(P)= \pm 0.25$ bar. Although all valves from the piston pump to the PVT cell are open, meaning all monitoring points will read the same, P2 is used for hydrate experiments in this study due to its proximity to the reaction mixture. This allows a quicker response to pressure changes from heating and cooling, gas consumption during hydrate formation and the release of gas from hydrate during dissociation.

For temperature monitoring, thermocouples with an expanded uncertainty of $U(T)=0.075^{\circ} \mathrm{C}$ allow temperature monitoring of the gas (T2) and water-hydrate (T3). The temperature of the water-hydrate mixture is of primary interest as it is a far better indicator of the equilibrium temperature than the gas phase. The thermocouple at position T3 is designated as the controlled thermocouple. Temperature is controlled using FALCON software which utilizes PID control. The desired temperature can be input or the rate of temperature change with time can be specified, which is particularly useful for hydrate experiments because of the low heating and cooling rates required for accurate hydrate equilibrium measurements (Tohidi, et al., 2000). The chiller is used for cooling procedures and uses cooling water as the coolant. Heating is supplied by an electrical heater. Heating and cooling rates are aided with the implemented circulating fan in the air bath chamber.

When gas is required for sampling and subsequent analysis, the gas is drawn from one of the sample points of the flow loop and sent to an MSR methane composition analyser. The analyser is also used to confirm the initial compositions that were calculated based on weighing by difference of pressurized gas canisters used to transfer gas into the flow loop. A line dedicated to venting purposes is used to dispose of used gas from both the analyser and PVT cell. The waste gas is directed to an outlet where it is safely released into the atmosphere.

\subsection{Operating Requirements}

As with any form of experimentation, it is essential for the apparatus to be free from foreign agents that may interfere. For this reason, purging with $\mathrm{N}_{2}$ was a necessary measure before hydrate experiments could be conducted. This was followed by vacuuming of the system to remove residual $\mathrm{N}_{2}$ and any remaining contaminants. Thorough cleaning of the cell was also required to remove debris that can sometimes deposit on the inside of the glass.

Temperature control was performed in small increments for cooling and heating processes to ensure that the identification of phase changes are clear and distinguishable. High heating and cooling rates can introduce significant human error, especially since the observation of hydrate formation and dissociation relies on human observation in this study. Therefore, high heating and cooling rates can cause unreliable and biased equilibria (Tohidi, et al., 2000). 
Temperature changes were consequently required to be performed in small increments so that high heat transfer rates are avoided.

\subsection{Experimental Procedure}

Stainless steel canisters pressurized with pre-determined quantities of gas were released into the piston pump via a manifold and then allowed to enter the cell. Pressurization of the gas was furthered according to the required pressure and allowed to thermally equilibrate. To determine hydrate equilibrium conditions, the isochoric temperature-search method was chosen because it complements the configuration of the apparatus. The contents were cooled in small increments until the formation of hydrates occurred, which were left to develop completely. To promote hydrate formation and growth, the magnetic actuator was set to approximately $300 \mathrm{rpm}$. The developed hydrate solid was heated in increments, ensuring a clear observation of the hydrate dissociation/ equilibrium point. Heating was continued to dissociate the hydrate completely.

\subsection{Gas Preparation}

The pure gases used for gas mixture preparation were supplied by BOC Australia and were high purity scientific grade. Table 1 lists the materials used.

\begin{tabular}{|l|c|c|}
\hline \multicolumn{3}{|c|}{ Table 1 - Experimental Materials } \\
Gas & Purity $^{\text {a }}(\mathrm{mol} \%)$ & Supplier \\
\hline Methane & $>99.995$ & BOC Aus. \\
Propane & $>99.99$ & BOC Aus. \\
i-Butane & $>99.99$ & BOC Aus. \\
n-Butane & $>99.99$ & BOC Aus. \\
Nitrogen & $>99.99$ & BOC Aus. \\
Distilled water & - & Laboratory-made \\
\hline
\end{tabular}

The gas mixtures were prepared by pressurizing stainless steel canisters with binary and in some cases mixtures of $\mathrm{C}_{1}+\mathrm{C}_{3} / \mathrm{iC}_{4} / \mathrm{nC}_{4}+\mathrm{N}_{2}$. All mixtures constituted $\mathrm{C}_{1}$ as the filler. All canisters were filled to an estimated pressure that when combined, the resultant mixture would be of the desired composition. Calculations using the Peng-Robinson equation of state were used as an estimation of the amount of gas and pressures required (Peng \& Robinson, 1976). Weighing-by-difference of the canisters confirmed the compositions of the 
gases. An example is provided for the preparation of the $\mathrm{C}_{1}(78.948 \mathrm{~mol} \%), \mathrm{C}_{3}(5.026 \mathrm{~mol} \%)$ and $\mathrm{N}_{2}(16.026 \mathrm{~mol} \%)$ gas mixture in Table 2.

\begin{tabular}{|c|c|c|c|}
\hline \multicolumn{4}{|c|}{ Table 2 - Gas Weighing: Example Procedure } \\
\hline & Cylinder $1\left(\mathrm{C}_{1}\right)$ & Cylinder $2\left(\mathrm{C}_{3}\right)$ & Cylinder $3\left(\mathrm{~N}_{2}\right)$ \\
\hline Filled $(g)$ & 1632.154 & 1594.763 & 1537.854 \\
\hline Emptied (g) & 1600.893 & 1589.222 & 1526.773 \\
\hline Gas (g) & 31.261 & 5.541 & 11.081 \\
\hline Moles & 1.9486 & 0.12405 & 0.39574 \\
\hline Composition (mol\%) & 78.948 & 5.026 & 16.026 \\
\hline Expanded uncertainty (mol\%)a & \pm 0.003 & \pm 0.001 & \pm 0.001 \\
\hline
\end{tabular}

${ }^{\text {aAt }} 95 \%$ level of confidence

All gas mixtures prepared for hydrate experimentation in this study had similar uncertainties as detailed in Table 2. Expanded uncertainties for the compositions were calculated according to the balance's stated uncertainty of $\pm 0.0005 \mathrm{~g}$.

\subsection{Uncertainty Evaluation}

The experimental and calculated parameters based on experimental data presented in the following sections have an uncertainty that is determined according to guidelines in ISO's Guide to the Expression of Uncertainty in Measurement (GUM) (2008). The uncertainties for the pressure reading, temperature reading and gas preparation were considered and are represented as expanded uncertainties (U).

For example, in calculating the combined standard uncertainty for the pressure or temperature reading, the sources (i) that contribute are transmitter uncertainty, temperature effect, calibration, stability and data scatter. A root-mean-square average of the mentioned sources of uncertainty was calculated to give a combined standard uncertainty. Expanded uncertainties are calculated with a $95 \%$ level of confidence $(k=2)$.

- Standard uncertainty for $\mathrm{i}=\mathrm{u}_{\mathrm{i}}$ at $95 \%$ level of confidence

- Sensitivity $\left(\mathrm{c}_{\mathrm{i}}\right)$ weighted standard uncertainty: $\mathrm{u}_{\mathrm{i}} \mathrm{c}_{\mathrm{i}}$

- Combined standard uncertainty of measured parameter $(y): u(y)=\operatorname{sqrt} \sum_{i}\left(u_{i} c_{i}\right)^{2}$

- Expanded uncertainty: $U=k u(y)$ 
The expanded uncertainty for pressure, $U(P)$, is \pm 0.25 bar. For temperature, $U(T)$ varied between each pressure-temperature point due to scatter and ranged from \pm 0.1 to $\pm 0.2{ }^{\circ} \mathrm{C}$. Dissociation enthalpies $\left(\Delta H_{d}\right)$ in section 3.2 were characterised using both temperature and pressure measurements. Given that a set of equilibrium pressures and temperatures were used to calculate the dissociation enthalpy for that particular set, $\mathrm{U}\left(\Delta H_{d}\right)$ was also variable and ranged from \pm 0.6 to $\pm 1.0 \mathrm{~kJ} / \mathrm{mol}$.

\section{Results and Discussions}

\subsection{Hydrate Equilibrium Results}

In the presence of water, the hydrate of most natural gases is sll (Sloan \& Koh, 2008).

Natural gas hydrates constitute intermediate hydrocarbons such as $\mathrm{C}_{3}$ and the butanes, particularly $\mathrm{iC}_{4}$, and form sll hydrates by occupying the large $5^{12} 6^{4}$ lattice cages (Kini, et al., 2004). The primary natural gas constituent, $C_{1}$, fills the smaller $5^{12}$ cage and together with a sll former, stabilise the hydrate lattice (Sloan \& Koh, 2008). Natural gas can often contain small concentrations of $\mathrm{C}_{3}, \mathrm{i}_{4}$ and $\mathrm{nC}_{4}$. Small concentrations of these hydrocarbons with $\mathrm{C}_{1}$ can have a large effect on their hydrate equilibrium conditions relative to pure $C_{1}$. The proceeding results demonstrate the promotion of $\mathrm{C}_{1}$ equilibria when subjected to low concentrations of sll formers. Phase equilibrium curves are constructed via individual data points with an exponential least-squares fitted line. 


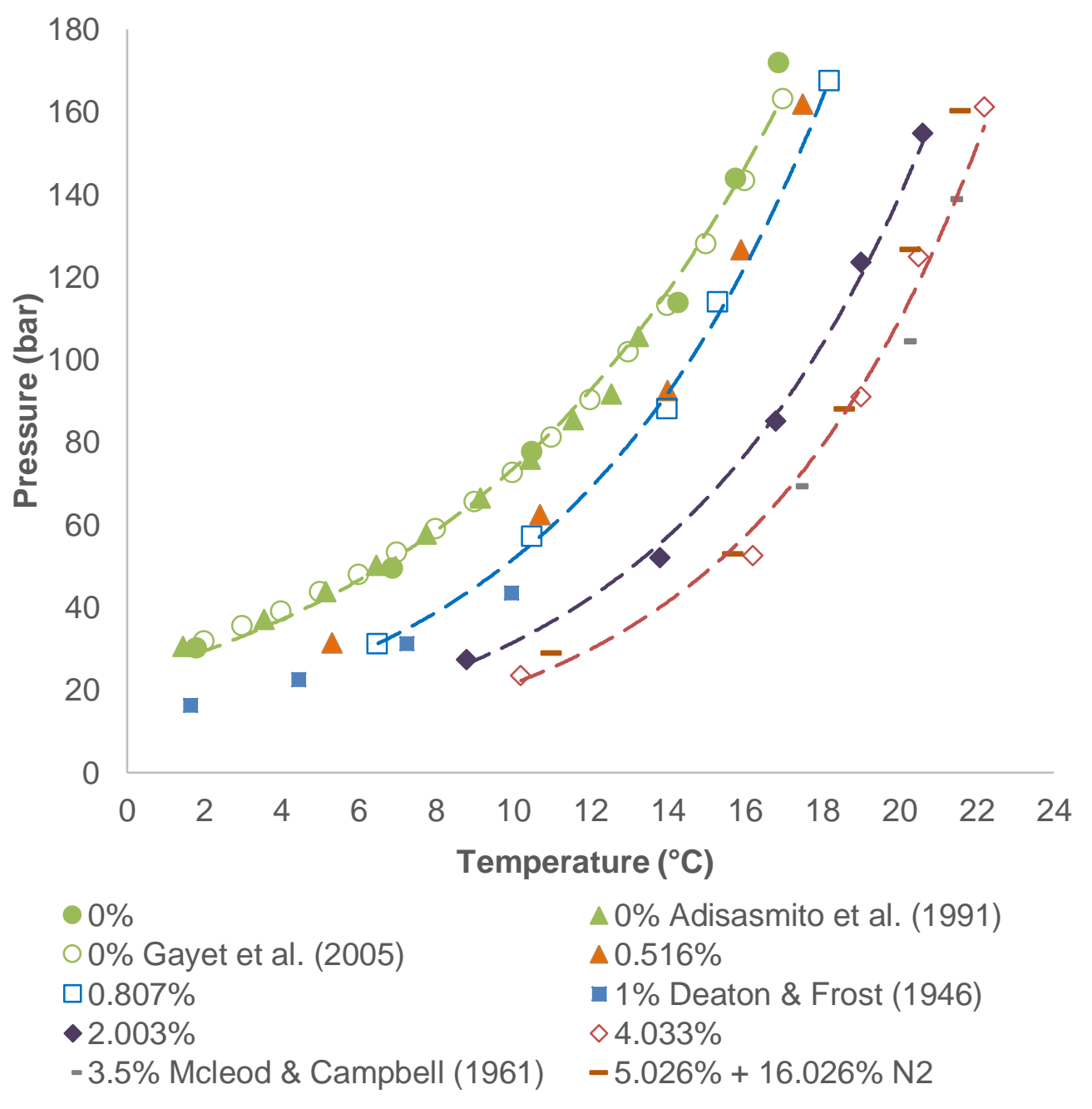

Figure 2 - Methane-Propane Hydrate Equilibria 


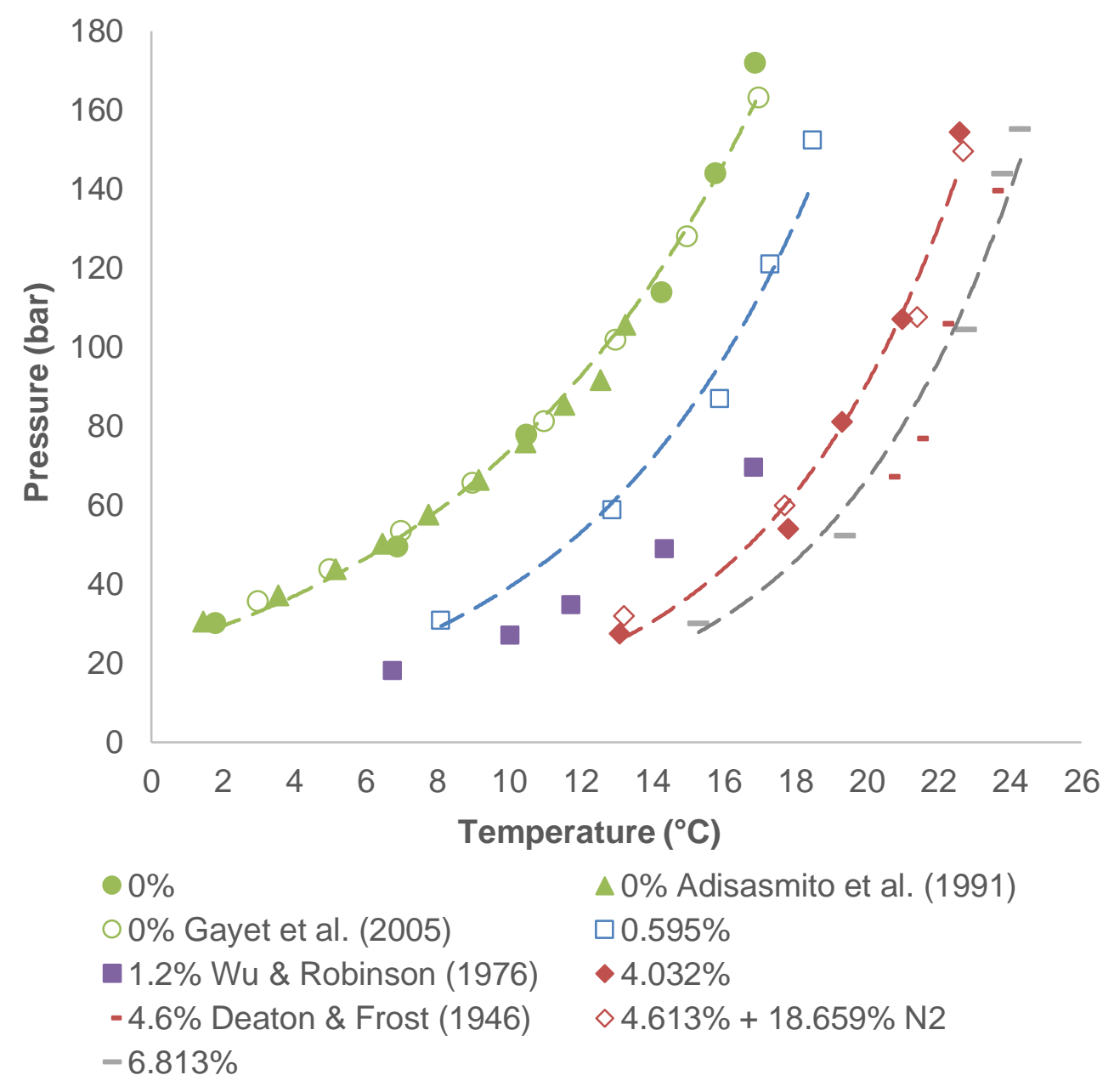

Figure 3 - Methane-i-Butane Hydrate Equilibria 


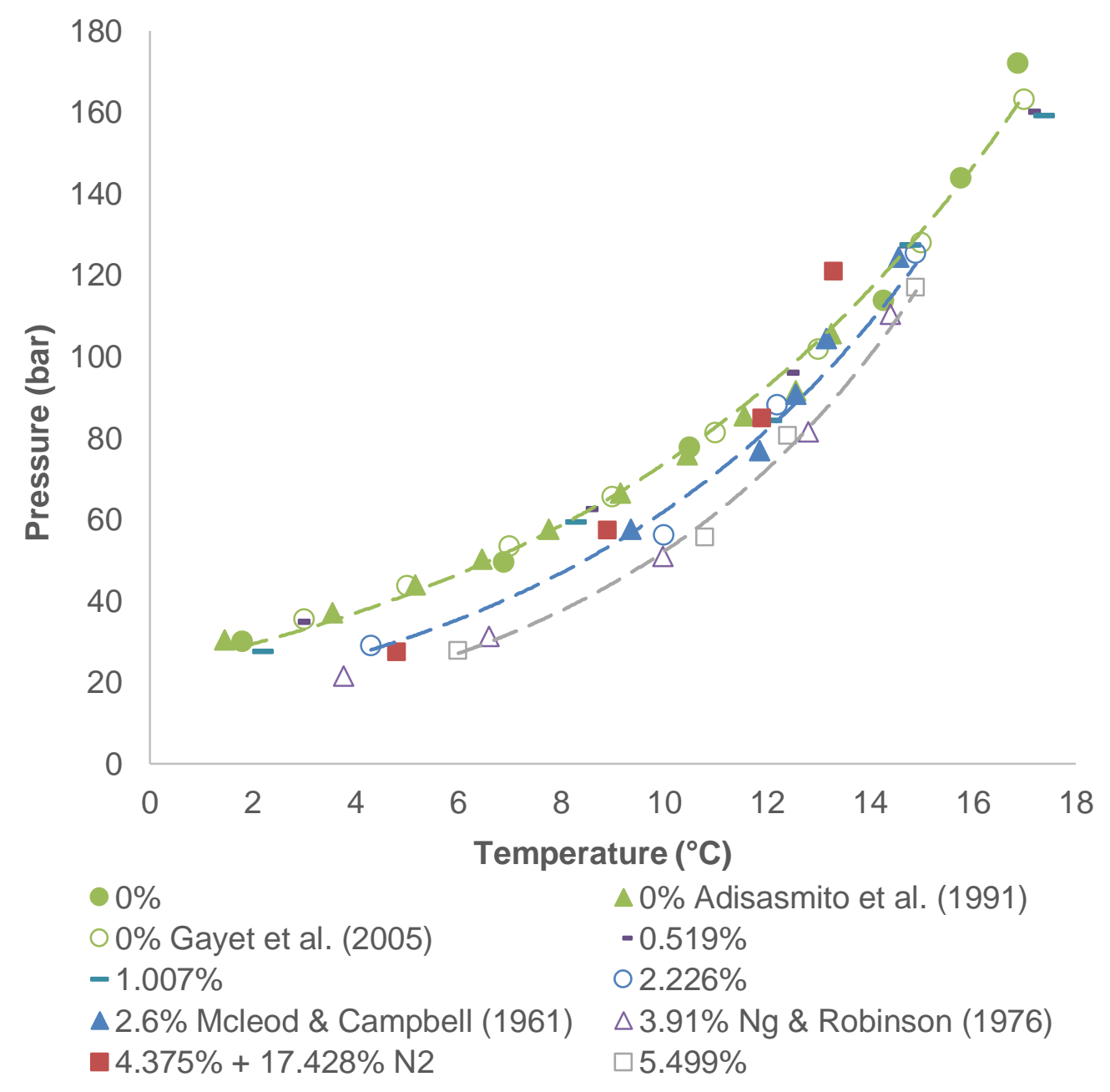

Figure 4 - Methane-n-Butane Hydrate Equilibria 


\begin{tabular}{|c|c|c|c|c|c|}
\hline \multicolumn{2}{|c|}{$\begin{array}{c}C_{1} \\
(100.000)\end{array}$} & \multicolumn{2}{|c|}{$\begin{array}{c}C_{1} / C_{3} \\
(99.484 / 0.516)\end{array}$} & \multicolumn{2}{|c|}{$\begin{array}{c}C_{1} / C_{3} \\
(99.193 / 0.807)\end{array}$} \\
\hline P/bar & $\mathbf{T} /{ }^{\circ} \mathbf{C}$ & P/bar & $\mathrm{T} /{ }^{\circ} \mathbf{C}$ & P/bar & $\mathbf{T} /{ }^{\circ} \mathbf{C}$ \\
\hline 31.25 & $1.8 \pm 0.1$ & 31.34 & $5.3 \pm 0.1$ & 31.00 & $6.5 \pm 0.1$ \\
\hline 49.38 & $6.9 \pm 0.1$ & 62.45 & $10.7 \pm 0.1$ & 57.10 & $10.6 \pm 0.1$ \\
\hline 77.66 & $10.5 \pm 0.1$ & 92.61 & $14.0 \pm 0.2$ & 88.01 & $14.0 \pm 0.1$ \\
\hline 113.71 & $14.3 \pm 0.1$ & 126.57 & $15.9 \pm 0.2$ & 113.88 & $15.3 \pm 0.2$ \\
\hline 143.80 & $15.8 \pm 0.1$ & 161.84 & $17.5 \pm 0.1$ & 167.50 & $18.2 \pm 0.1$ \\
\hline 171.89 & $16.9 \pm 0.1$ & & & & \\
\hline \multicolumn{2}{|c|}{$\mathrm{U}\left(\mathrm{C}_{1}\right)= \pm 0.000 \mathrm{~mol} \%$} & \multicolumn{2}{|c|}{$\begin{array}{l}\mathrm{U}\left(\mathrm{C}_{1}\right)= \pm 0.002, \mathrm{U}\left(\mathrm{C}_{3}\right)= \pm 0.001 \\
\mathrm{~mol} \%\end{array}$} & \multicolumn{2}{|c|}{$\begin{array}{l}\left.\mathrm{U}\left(\mathrm{C}_{1}\right)= \pm 0.002, \mathrm{UC}_{3}\right)= \pm 0.001 \\
\mathrm{~mol} \%\end{array}$} \\
\hline \multicolumn{2}{|c|}{$\begin{array}{c}\mathrm{C}_{1} / \mathrm{C}_{3} \\
(97.997 / 2.003)\end{array}$} & \multicolumn{2}{|c|}{$\begin{array}{c}\mathrm{C}_{1} / \mathrm{C}_{3} \\
(95.967 / 4.033)\end{array}$} & \multicolumn{2}{|c|}{$\begin{array}{c}\mathrm{C}_{1} / \mathrm{C}_{3} / \mathrm{N}_{2} \\
(78.948 / 5.026 / 16.026)\end{array}$} \\
\hline P/bar & $\mathbf{T} /{ }^{\circ} \mathbf{C}$ & P/bar & $\mathrm{T} /{ }^{\circ} \mathbf{C}$ & P/bar & $\mathrm{T} /{ }^{\circ} \mathrm{C}$ \\
\hline 27.43 & $8.8 \pm 0.1$ & 23.60 & $10.2 \pm 0.1$ & 28.90 & $11.0 \pm 0.2$ \\
\hline 52.02 & $13.8 \pm 0.2$ & 52.62 & $16.2 \pm 0.2$ & 52.89 & $15.7 \pm 0.1$ \\
\hline 85.20 & $16.8 \pm 0.1$ & 91.09 & $19.0 \pm 0.1$ & 87.96 & $18.6 \pm 0.2$ \\
\hline 123.61 & $19.0 \pm 0.1$ & 124.98 & $20.5 \pm 0.2$ & 126.56 & $20.3 \pm 0.1$ \\
\hline 154.92 & $20.6 \pm 0.1$ & 161.30 & $22.2 \pm 0.1$ & 160.27 & $21.6 \pm 0.1$ \\
\hline \multicolumn{2}{|c|}{$\begin{array}{l}\left.\mathrm{UC}_{1}\right)= \pm 0.002, \mathrm{U}\left(\mathrm{C}_{3}\right)= \pm 0.001 \\
\mathrm{~mol} \%\end{array}$} & \multicolumn{2}{|c|}{$\begin{array}{l}\mathrm{U}\left(\mathrm{C}_{1}\right)= \pm 0.002, \mathrm{U}\left(\mathrm{C}_{3}\right)= \pm 0.001 \\
\mathrm{~mol} \%\end{array}$} & \multicolumn{2}{|c|}{$\begin{array}{l}\mathrm{U}\left(\mathrm{C}_{1}\right)= \pm 0.003, \mathrm{U}\left(\mathrm{C}_{3}\right)= \pm 0.001 \\
\mathrm{U}\left(\mathrm{N}_{2}\right)= \pm 0.001 \mathrm{~mol} \%\end{array}$} \\
\hline \multicolumn{2}{|c|}{$\begin{array}{c}\mathrm{C}_{1} / \mathrm{iC}_{4} \\
(99.405 / 0.595)\end{array}$} & \multicolumn{2}{|c|}{$\begin{array}{c}\mathrm{C}_{1} / \mathrm{iC}_{4} \\
(95.968 / 4.032)\end{array}$} & \multicolumn{2}{|c|}{$\begin{array}{c}\mathrm{C}_{1} / \mathrm{iC}_{4} \\
(93.187 / 6.813)\end{array}$} \\
\hline P/bar & $\mathbf{T} /{ }^{\circ} \mathbf{C}$ & P/bar & $\mathbf{T} /{ }^{\circ} \mathbf{C}$ & P/bar & $\mathbf{T} /{ }^{\circ} \mathbf{C}$ \\
\hline 30.68 & $8.1 \pm 0.1$ & 27.45 & $13.1 \pm 0.1$ & 30.11 & $15.3 \pm 0.1$ \\
\hline 58.65 & $12.9 \pm 0.1$ & 54.10 & $17.8 \pm 0.2$ & 52.31 & $19.4 \pm 0.2$ \\
\hline 86.83 & $15.9 \pm 0.2$ & 81.20 & $19.3 \pm 0.1$ & 104.42 & $22.8 \pm 0.1$ \\
\hline 120.90 & $17.3 \pm 0.1$ & 107.11 & $21.0 \pm 0.1$ & 143.93 & $23.8 \pm 0.1$ \\
\hline 152.27 & $18.5 \pm 0.1$ & 154.51 & $22.6 \pm 0.1$ & 155.24 & $24.3 \pm 0.1$ \\
\hline \multicolumn{2}{|c|}{$\begin{array}{l}\mathrm{U}\left(\mathrm{C}_{1}\right)= \pm 0.002, \mathrm{U}\left(\mathrm{iC}_{4}\right)= \pm 0.001 \\
\mathrm{~mol} \%\end{array}$} & \multicolumn{2}{|c|}{$\begin{array}{l}\mathrm{U}\left(\mathrm{C}_{1}\right)= \pm 0.002, \mathrm{U}\left(\mathrm{iC}_{4}\right)= \pm 0.001 \\
\mathrm{~mol} \%\end{array}$} & \multicolumn{2}{|c|}{$\begin{array}{l}\mathrm{U}\left(\mathrm{C}_{1}\right)= \pm 0.002, \mathrm{U}\left(\mathrm{iC}_{4}\right)= \pm 0.001 \\
\mathrm{~mol} \%\end{array}$} \\
\hline \multicolumn{2}{|c|}{$\begin{array}{c}\mathrm{C}_{1} / \mathrm{iC}_{4} / \mathrm{N}_{2} \\
(76.728 / 4.613 / 18.659)\end{array}$} & \multicolumn{2}{|c|}{$\begin{array}{c}\mathrm{C}_{1} / \mathrm{nC}_{4} \\
(99.481 / 0.519)\end{array}$} & \multicolumn{2}{|c|}{$\begin{array}{c}\mathrm{C}_{1} / \mathrm{nC}_{4} \\
(98.993 / 1.007)\end{array}$} \\
\hline P/bar & $\mathbf{T} /{ }^{\circ} \mathbf{C}$ & P/bar & $\mathrm{T} /{ }^{\circ} \mathbf{C}$ & P/bar & $\mathrm{T} /{ }^{\circ} \mathbf{C}$ \\
\hline 31.91 & $13.2 \pm 0.1$ & 34.83 & $2.9 \pm 0.1$ & 27.52 & $2.2 \pm 0.1$ \\
\hline 60.01 & $17.7 \pm 0.1$ & 62.57 & $8.5 \pm 0.1$ & 59.37 & $8.3 \pm 0.1$ \\
\hline 107.65 & $21.4 \pm 0.1$ & 96.05 & $12.4 \pm 0.1$ & 84.22 & $12.1 \pm 0.2$ \\
\hline
\end{tabular}




\begin{tabular}{|c|c|c|c|c|c|}
\hline 149.63 & $22.7 \pm 0.1$ & $\begin{array}{l}127.33 \\
160.14\end{array}$ & $\begin{array}{l}14.6 \pm 0.2 \\
17.1 \pm 0.1\end{array}$ & $\begin{array}{l}127.31 \\
159.06\end{array}$ & $\begin{array}{l}14.8 \pm 0.1 \\
17.4 \pm 0.1\end{array}$ \\
\hline \multicolumn{2}{|c|}{$\begin{array}{l}\mathrm{U}\left(\mathrm{C}_{1}\right)= \pm 0.002, \mathrm{U}\left(\mathrm{iC}_{4}\right)= \pm 0.001 \\
\mathrm{U}\left(\mathrm{N}_{2}\right)= \pm 0.001 \mathrm{~mol} \%\end{array}$} & \multicolumn{2}{|c|}{$\begin{array}{l}\mathrm{U}\left(\mathrm{C}_{1}\right)= \pm 0.002, \mathrm{U}\left(\mathrm{nC}_{4}\right)= \pm 0.001 \\
\mathrm{~mol} \%\end{array}$} & \multicolumn{2}{|c|}{$\begin{array}{l}\mathrm{U}\left(\mathrm{C}_{1}\right)= \pm 0.002, \mathrm{U}\left(\mathrm{nC}_{4}\right)= \pm 0.001 \\
\mathrm{~mol} \%\end{array}$} \\
\hline \multicolumn{2}{|c|}{$\begin{array}{c}\mathrm{C}_{1} / \mathrm{nC}_{4} \\
(97.774 / 2.226)\end{array}$} & \multicolumn{2}{|c|}{$\begin{array}{c}\mathrm{C}_{1} / \mathrm{nC}_{4} \\
(94.501 / 5.499)\end{array}$} & \multicolumn{2}{|c|}{$\begin{array}{c}\mathrm{C}_{1} / \mathrm{nC}_{4} / \mathrm{N}_{2} \\
(78.197 / 4.375 / 17.428)\end{array}$} \\
\hline $\mathrm{P} / \mathrm{bar}$ & $\mathbf{T} /{ }^{\circ} \mathbf{C}$ & P/bar & $\mathrm{T} /{ }^{\circ} \mathbf{C}$ & P/bar & $\mathbf{T} /{ }^{\circ} \mathbf{C}$ \\
\hline 29.00 & $4.5 \pm 0.1$ & 27.70 & $6.0 \pm 0.1$ & 27.45 & $4.8 \pm 0.1$ \\
\hline 56.07 & $9.9 \pm 0.2$ & 55.51 & $10.8 \pm 0.1$ & 57.30 & $8.9 \pm 0.1$ \\
\hline 88.13 & $12.0 \pm 0.1$ & 80.61 & $12.4 \pm 0.2$ & 84.83 & $11.9 \pm 0.1$ \\
\hline 125.30 & $14.9 \pm 0.1$ & 116.84 & $14.9 \pm 0.1$ & 120.90 & $13.3 \pm 0.2$ \\
\hline \multicolumn{2}{|c|}{$\begin{array}{l}\mathrm{U}\left(\mathrm{C}_{1}\right)= \pm 0.002, \mathrm{U}\left(\mathrm{nC}_{4}\right)= \pm 0.001 \\
\mathrm{~mol} \%\end{array}$} & \multicolumn{2}{|c|}{$\begin{array}{l}\mathrm{U}\left(\mathrm{C}_{1}\right)= \pm 0.003, \mathrm{U}\left(\mathrm{nC}_{4}\right)= \pm 0.001 \\
\mathrm{~mol} \%\end{array}$} & \multicolumn{2}{|c|}{$\begin{array}{l}\mathrm{U}\left(\mathrm{C}_{1}\right)= \pm 0.002, \mathrm{U}\left(\mathrm{nC}_{4}\right)= \pm 0.001, \\
\mathrm{U}\left(\mathrm{N}_{2}\right)= \pm 0.001 \mathrm{~mol} \%\end{array}$} \\
\hline
\end{tabular}

${ }^{\text {b}}$ All uncertainties are expanded uncertainties $(U)$ at $95 \%$ level of confidence: $U(P)= \pm 0.25$ bar; $U(T)$ is as specified 


\begin{tabular}{|c|c|c|c|c|c|}
\hline \multirow{2}{*}{\multicolumn{2}{|c|}{$\begin{array}{c}C_{1} \\
(100)\end{array}$}} & \multirow{2}{*}{\multicolumn{2}{|c|}{$\begin{array}{c}C_{1} \\
(100)\end{array}$}} & \multirow{2}{*}{\multicolumn{2}{|c|}{$\begin{array}{l}C_{1} / C_{3} \\
(99 / 1)\end{array}$}} \\
\hline & & & & & \\
\hline P/bar & $\mathrm{T} /{ }^{\circ} \mathbf{C}$ & P/bar & $\mathbf{T} /{ }^{\circ} \mathbf{C}$ & P/bar & $\mathbf{T} /{ }^{\circ} \mathbf{C}$ \\
\hline 35.5 & 3.0 & 30.5 & 1.45 & 16.27 & 1.65 \\
\hline 43.6 & 5.0 & 37.2 & 3.55 & 22.47 & 4.45 \\
\hline 53.3 & 7.0 & 43.9 & 5.15 & 31.23 & 7.25 \\
\hline 65.5 & 9.0 & 50.2 & 6.45 & 43.58 & 9.95 \\
\hline 81.2 & 11.0 & 57.7 & 7.75 & & \\
\hline 101.7 & 13.0 & 66.5 & 9.15 & & \\
\hline 127.9 & 15.0 & 75.9 & 10.45 & & \\
\hline \multirow[t]{3}{*}{163.0} & 17.0 & 85.5 & 11.55 & & \\
\hline & & 91.7 & 12.55 & & \\
\hline & & 105.7 & 13.25 & & \\
\hline \multicolumn{2}{|c|}{ Gayet et al. (2005) } & \multicolumn{2}{|c|}{ Adisasmito et al. (1991) } & \multicolumn{2}{|c|}{ Deaton \& Frost (1946) } \\
\hline \multirow{2}{*}{\multicolumn{2}{|c|}{$\begin{array}{c}C_{1} / C_{3} \\
(96.5 / 3.5)\end{array}$}} & \multirow{2}{*}{\multicolumn{2}{|c|}{$\begin{array}{c}\mathrm{C}_{1} / \mathrm{iC}_{4} \\
(99.8 / 1.2)\end{array}$}} & \multirow{2}{*}{\multicolumn{2}{|c|}{$\begin{array}{c}\mathrm{C}_{1} / \mathrm{iC}_{4} \\
(95.4 / 4.6)\end{array}$}} \\
\hline & & & & & \\
\hline P/bar & $\mathbf{T} /{ }^{\circ} \mathbf{C}$ & P/bar & $\mathbf{T} /{ }^{\circ} \mathbf{C}$ & P/bar & $\mathbf{T} /{ }^{\circ} \mathbf{C}$ \\
\hline 69.3 & 1.65 & 18.0 & 6.75 & 67.2 & 20.65 \\
\hline 104.5 & 4.45 & 27.0 & 10.05 & 76.9 & 21.45 \\
\hline \multirow[t]{3}{*}{138.9} & 7.25 & 34.7 & 11.75 & 105.8 & 22.15 \\
\hline & & 48.8 & 14.35 & 139.6 & 23.55 \\
\hline & & 69.6 & 16.85 & & \\
\hline \multicolumn{2}{|c|}{ Mcleod \& Campbell (1961) } & \multicolumn{2}{|c|}{ Wu \& Robinson (1976) } & Mcl & npbell (1961) \\
\hline \multirow{2}{*}{\multicolumn{2}{|c|}{$\begin{array}{c}\mathrm{C}_{1} / \mathrm{nC}_{4} \\
(97.4 / 2.6)\end{array}$}} & \multirow{2}{*}{\multicolumn{2}{|c|}{$\begin{array}{c}\mathrm{C}_{1} / \mathrm{nC}_{4} \\
(96.09 / 3.91)\end{array}$}} & & \\
\hline & & & & & \\
\hline P/bar & $\mathbf{T} /{ }^{\circ} \mathbf{C}$ & P/bar & $\mathbf{T} /{ }^{\circ} \mathbf{C}$ & & \\
\hline 57.6 & 9.35 & 21.5 & 3.76 & & \\
\hline 76.9 & 11.85 & 31.4 & 6.59 & & \\
\hline 90.7 & 12.55 & 50.9 & 9.97 & & \\
\hline 104.5 & 13.15 & 81.6 & 12.8 & & \\
\hline 124.5 & 14.55 & 110.5 & 14.4 & & \\
\hline \multicolumn{2}{|c|}{ Mcleod \& Campbell (1961) } & \multicolumn{2}{|c|}{ Ng \& Robinson (1976) } & & \\
\hline
\end{tabular}

The hydrate equilibria for $\mathrm{C}_{1}-\mathrm{C}_{3}$ in water has previously been documented by several workers (Deaton \& Frost, 1946); (Mcleod \& Campbell, 1961). The promoting influence of $\mathrm{C}_{3}$ 
in the presence of $\mathrm{C}_{1}$ is apparent and such an effect on the hydrate equilibria with $\mathrm{C}_{1}$ can also be interpreted from studies performed by Mcleod, Song and co-workers (Mcleod \& Campbell, 1961); (Song \& Kobayashi, 1982). Likewise, the equilibria for $\mathrm{C}_{1}-\mathrm{i} \mathrm{C}_{4} / \mathrm{nC}_{4}$ in water is also documented (Deaton \& Frost, 1946); (Wu, et al., 1976); (Mcleod \& Campbell, 1961); ( $\mathrm{Ng} \&$ Robinson, 1976). However, studies focusing on small $\mathrm{C}_{3} / \mathrm{iC}_{4} / \mathrm{nC}_{4}$ compositions are uncommon. Very little literature material also deals with the effect of $\mathrm{N}_{2}$ on these hydrate equilibria. Pressures greater than 250 bar are required for $\mathrm{N}_{2}$ hydrates to form, which is beyond the $\mathrm{N}_{2}$ partial pressures investigated (van Cleef \& Diepen, 1960). Therefore, the little to no occupation of cavities by $\mathrm{N}_{2}$ at a low enough partial pressure can counteract the promoting influence of $\mathrm{C}_{3}, \mathrm{iC}_{4}$ or $\mathrm{nC}_{4}$ by dilution. $\mathrm{N}_{2}$ dilution of the tested gas mixtures was performed and their relative effects on hydrate equilibrium promotion by sll species are discussed.

\subsubsection{Methane-Propane \& Methane-i-Butane}

Figure 2 and Figure 3 present experimental hydrate equilibria for the mentioned gas mixtures in addition to the inclusion of $\mathrm{N}_{2}$ in such systems. Modelling software (PVTsim v.20 with Peng-Robinson equation of state) provided validity to the $\mathrm{C}_{3}$ and $\mathrm{iC}_{4}$ data, with mostly minor discrepancies. A clear indication of $\mathrm{C}_{3}$ and $\mathrm{iC}_{4}$ 's synergistic effect on equilibria promotion with $\mathrm{C}_{1}$ are their $<1$ mol\% curves ( 0.807 and 0.595 mol\% respectively), which depict a greater equilibrium temperature $\left(T_{\text {eq }}\right)$ than pure $\mathrm{C}_{1}$ at any of tested pressures. Given their small abundance, an observed shift ranging from $1-5^{\circ} \mathrm{C}$ with respect to pure $C_{1}$ for $C_{3}$ (0.807 mol\%) and $2-6{ }^{\circ} \mathrm{C}$ for $\mathrm{iC}_{4}(0.595 \mathrm{~mol} \%)$ is significant. The $0.807 \mathrm{~mol} \% \mathrm{C}_{3}$ data is also consistent with Deaton \& Frost's (1946) 1 mol\% equilibria. $T_{e q}$ is slightly lower (at 0.807 mol\%) for the available pressure points. Similarly, the $0.595 \mathrm{~mol}_{\%} \mathrm{iC}_{4}$ results compare favourably with Wu and co-workers' $1.2 \mathrm{~mol} \% ~ \mathrm{iC}_{4}$ data - the presented work lies approximately halfway between the curve for $\mathrm{C}_{1}$ and literature data for $1.2 \mathrm{~mol} \%$.

Increasing the $\mathrm{C}_{3}$ concentration to $2.003 \mathrm{~mol} \%$ drastically amplifies the resulting gas mixture's equilibria. $T_{e q}$ now ranges from $4-6.5^{\circ} \mathrm{C}$ higher than pure $\mathrm{C}_{1}$. Further increasing the composition to $4.033 \mathrm{~mol} \%$ understandably increases $T_{\text {eq }}$, but this increase is less pronounced, i.e. as the $\mathrm{C}_{3}$ concentration increases, the subsequent increase in $T_{\text {eq }}$ reduces in magnitude at a given pressure. A similar phenomenon occurs when increasing $\mathrm{iC}_{4}$ concentration to $4.033 \mathrm{~mol} \%$ and further to $6.813 \mathrm{~mol} \%$. Reduced sensitivity of hydrate equilibria promotion is rationalised by realising that a hydrate lattice constitutes a limited quantity of cavities or adsorption sites and is described by the Langmuir isotherm in the van der Waals-Platteeuw (vdWP) model shown in Eq. 1 (van der Waals \& Platteeuw, 1959). Fractional occupancy of cavity type i by guest species $\mathrm{j}, \theta_{i j}$, is a function of the Langmuir 
constant, $C_{i j}$, and fugacity, $f_{i}$. The availability of cavities inevitably decreases as more cavities become occupied by guest molecules, giving rise to smaller and smaller increments in lattice stability (and $T_{e q}$ increase) as $f_{i}$ increases.

$$
\theta_{i j}=\frac{C_{i j} f_{i}}{1+\sum_{\mathrm{i}} C_{i j} f_{i}}
$$

The introduction of $\mathrm{N}_{2}$ to a $\mathrm{C}_{1}-\mathrm{C}_{3} / \mathrm{iC}_{4}$ gas mixture with water demonstrated suppressive effect of $\mathrm{N}_{2}$ on said hydrate system. Given the hydrate-inertness of $\mathrm{N}_{2}$ under this study's experimented pressures, the resulting effect is dilution of the hydrate guests (van Cleef \& Diepen, 1960); (Marshall, et al., 1964); (Jhaveri \& Robinson, 1965). In comparison to the $4.033 \mathrm{~mol} \% \mathrm{C}_{3}$ gas, the $5.026 \mathrm{~mol}^{\%} \mathrm{C}_{3}$ mixture with $\mathrm{N}_{2}(16.026 \mathrm{~mol} \%)$ in Figure 2 displays similar hydrate equilibria with approximately equivalent promotion (due to $\mathrm{C}_{3}$ ). The addition of $16.026 \mathrm{~mol} \% \mathrm{~N}_{2}$ means that the $\mathrm{C}_{1}$ concentration is lowered $(78.948 \mathrm{~mol} \%$ compared to $>96$ mol\% for $C_{1}-C_{3}$ mixtures), ensuring lower $f_{C 1}$ and less $C_{1} 5^{12}$ (s) cavity occupation, $\theta_{C 1, s}$. Similarly, the higher $\mathrm{C}_{3}$ concentration (5.026 to $4.033 \mathrm{~mol} \%$ ) provides an opposing, stabilising effect by increasing $f_{C 3}$ and therefore the $5^{12} 6^{4}(\mathrm{I})$ cavity occupation by $\mathrm{C}_{3}, \theta_{C 3, \mathrm{l}}$. Such an increase in $\theta_{C 3, \text { I }}$ is apparently significant enough to counteract the lowered $\theta_{C 1, s}$, resulting in both gas mixtures exhibiting similar overall hydrate equilibrium shifts relative to the pure $\mathrm{C}_{1}$ curve. This rationale also explains similar observations pertaining to the counteracting effects of $\mathrm{N}_{2}$ dilution and equilibria promotion via $\mathrm{iC}_{4}$ in Figure 3 for the $\mathrm{C}_{1}-\mathrm{iC}_{4}$ system.

\subsubsection{Methane-n-Butane}

For some time, $\mathrm{nC}_{4}$ was presumed to be unable to form hydrates (given the presence of water). Studies and reviews published in the mid-late 1960 s demonstrated that $\mathrm{nC}_{4}$ was seemingly incapable of forming hydrates (Musaev, 1966); (Byk \& Fomina, 1968). From a theoretical perspective, it was confirmed that the $\mathrm{nC}_{4}$ molecule was too large to fit into both the sl and sll cavities (Parrish \& Prausnitz, 1972). However, the presence of $C_{1}$ can act as a "help gas" and enables a hydrate phase consisting of $\mathrm{nC}_{4}$ and $\mathrm{C}_{1}$ to form (Mcleod \& Campbell, 1961); (Sloan \& Koh, 2008). Experimental results for $\mathrm{C}_{1}-\mathrm{nC}_{4}$ gas mixtures are presented in Figure 4.

Most notably, the introduction of $\mathrm{nC}_{4}$ to $\mathrm{C}_{1}$ provides far less promotion than $\mathrm{C}_{3}$ and $\mathrm{iC}_{4}$. This was by the thermodynamic models implemented in PVTsim when applied with the PengRobinson equation of state. An interesting observation is that as the $\mathrm{nC}_{4}$ composition is increased, the equilibrium curve becomes steeper to the point where it intersects with the $C_{1}$ curve. With the experimented $\mathrm{nC}_{4}$ compositions, this cross-over into the pure $\mathrm{C}_{1}$ hydrate's 
stability region occurs from approximately 80 - 120 bar. Mcleod and Campbell (1961) made similar observations. As pressure increases, cavities in the hydrate lattice can become distorted, slightly altering their dimensions - this phenomenon leads to difficulties regarding $\mathrm{nC}_{4}$ 's adsorption to the $5^{12} 6^{4}$ (large) structure II (sll) cavity ( $\mathrm{Ng} \&$ Robinson, 1976); (Stackelber \& Muller, 1951); (Claussen \& Frost, 1951). The filling of the large sll cavity by $\mathrm{nC}_{4}$ is not particularly favourable. Its molecule/cavity size ratio of 1.081 makes it difficult for $\mathrm{nC}_{4}$ to experience attractive van der Waals forces in the cavity due to overlap of $\mathrm{nC}_{4}$ and the water molecules' van der Waals radii (Lederhos, et al., 1993). It can be concluded that the combination of $\mathrm{nC}_{4}$ 's size and the effect of lattice distortion with pressure, adding $\mathrm{nC}_{4}$ to $\mathrm{C}_{1}$ can inhibit the hydrate phase equilibria by acting as a non-former.

\subsection{Dissociation Enthalpy Results}

In previous discussions (section 4.1), it was clear that small concentrations of a compatible hydrocarbon $\left(\mathrm{C}_{3}, \mathrm{iC}_{4}, \mathrm{nC}_{4}\right)$ additive to $\mathrm{C}_{1}$ could promote the hydrate equilibrium conditions quite substantially. The added component occupied the large cavity of the sll lattice, adding stability to the hydrate phase. Given that only relatively small concentrations were necessary to induce a promotion, it is of interest to confirm that the transition from $\mathrm{C}_{1}$ sl to $\mathrm{C}_{1}-\mathrm{C}_{3} / \mathrm{iC}_{4} / \mathrm{nC}_{4}$ sll hydrate is responsible for the observed promoting phenomena. The Clausius-Clapeyron equation is used and is represented as follows:

$$
\frac{\mathrm{d}(\ln P)}{\mathrm{d}(1 / T)}=\frac{\Delta H_{d}}{\mathrm{ZR}}
$$

The Clausius-Clapeyron equation relates $d(\operatorname{InP}) / d(1 / T)$ (slope) to the dissociation enthalpy of the hydrate, $\Delta H_{d}$. The $\mathrm{R}$ and $\mathrm{Z}$ symbols denote the gas constant and gas compressibility respectively. The slope and $\Delta H_{d}$ parameters are of particular importance because they are indicative of the hydrate structure type (Sloan \& Fleyfel, 1992). This form of the ClausiusClapeyron equation assumes that the volume change of the hydrate phase is insignificant compared to the volume of gas. Our experiments involved a relatively minute quantity of water, giving validity to this assumption. Hence, Eq. 2 can be applied to the data presented in the previous section to determine the hydrate structure type for a gas mixture.

It is well known that the slope and $\Delta H_{d}$ are proportional to the hydrate structure type and remain relatively constant for any abundance of the added hydrocarbon (Sloan \& Fleyfel, 1992); (Sloan \& Koh, 2008). Sloan and co-workers $(1992,2008)$ demonstrated that slopes in the regions of -8000 to -9000 and -14000 to $-16000 \mathrm{~K}$ are typical for sl and sll hydrates respectively. It is also understood that $\Delta H_{d}$ is dependent on how well the guest species fits into the hydrate cavity and the extent of occupation (Sloan \& Koh, 2008). From Eq. 1, higher concentrations (therefore fugacity) correspond to greater occupancy. We can therefore 
expect that $\Delta H_{d}$ (and slope) will increase when the concentration of $\mathrm{C}_{3} / \mathrm{iC}_{4} / \mathrm{nC}_{4}$ increases. Whilst comparing hydrate stability with the composition of the sll gas species would be more expressive, unfortunately, no single hydrate composition is reflective of the experimental data set required in the calculation of $\mathrm{d} / n P / \mathrm{d}(1 / T)$ and $\Delta H_{d}$. Figure 5 and Figure 6 consequently illustrate the increasing sll-like configuration with gas composition.

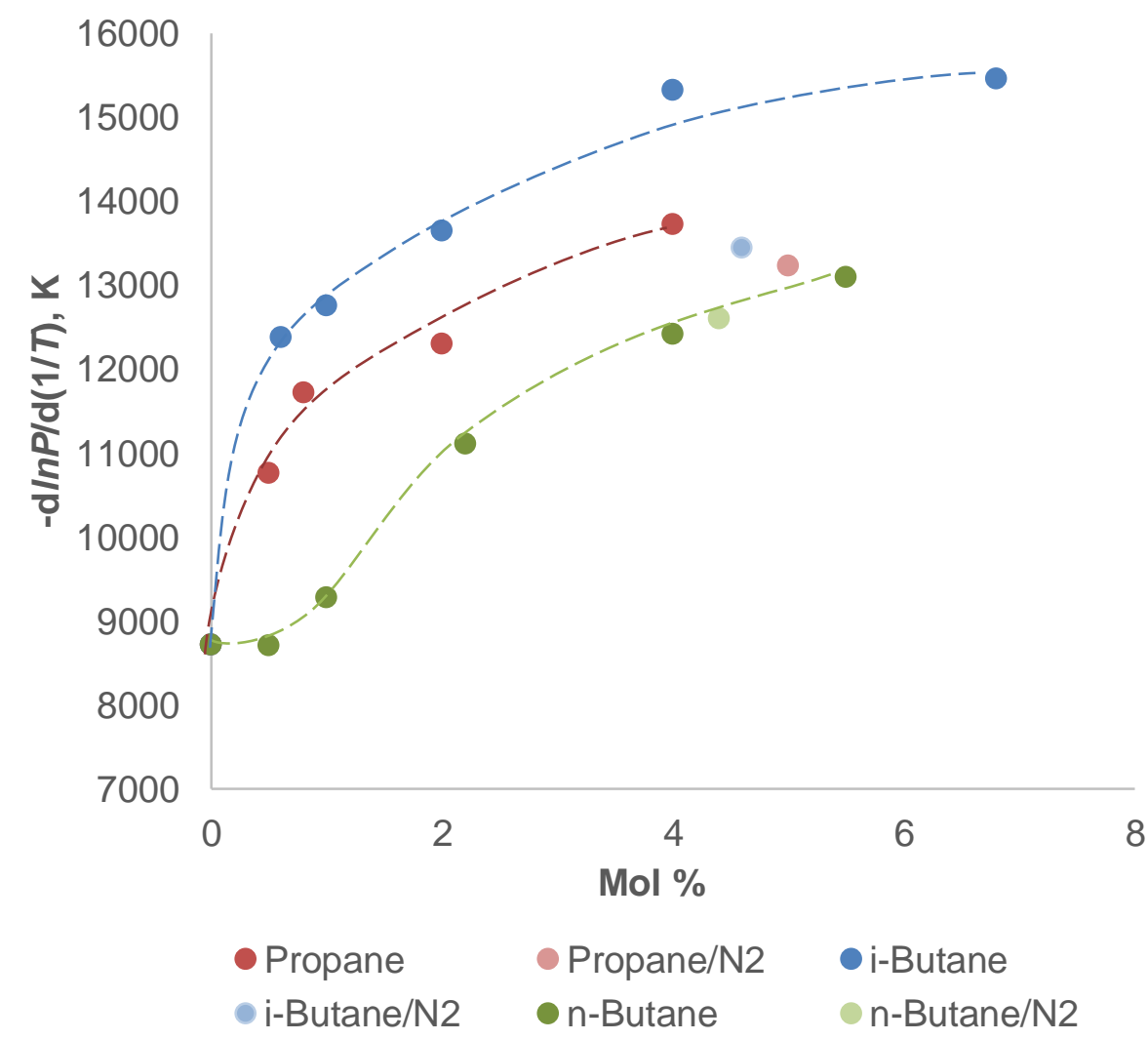

Figure $5-\mathrm{d}(\operatorname{In} P) / \mathrm{d}(\mathbf{1} / \mathrm{T})$ against Composition (0 - $8.0 \mathrm{~mol} \%)$ 


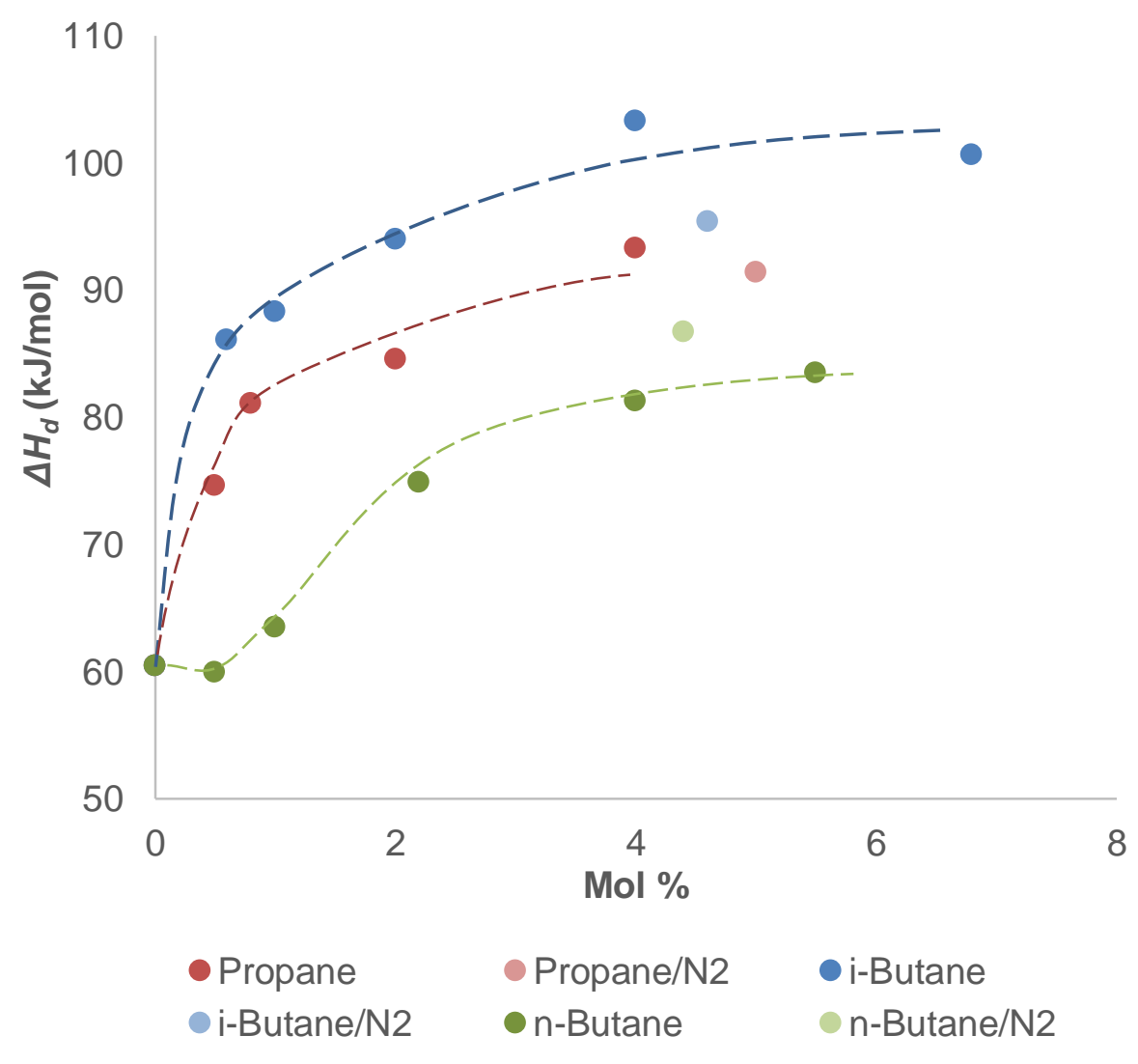

Figure $6-\Delta H_{d}$ against Composition (0 - 8.0 mol\%) 


\begin{tabular}{|c|c|c|c|}
\hline \multicolumn{4}{|c|}{ Table 5 - Hydrate Dissociation Enthalpy Data } \\
\hline Gas & $\begin{array}{c}\text { Composition } \\
\text { (mol\%) }\end{array}$ & $\begin{array}{c}\frac{\mathrm{d}(\ln P)}{\mathrm{d}(1 / T)} \\
(\mathrm{K})\end{array}$ & $\begin{array}{c}\Delta H_{d} \\
(\mathrm{~kJ} / \mathrm{mol})^{\mathrm{a}}\end{array}$ \\
\hline $\mathrm{C}_{1}$ & 100.000 & 8650 & $60.0 \pm 0.6$ \\
\hline $\mathrm{C}_{1} / \mathrm{C}_{3}$ & $\begin{array}{l}99.484 / 0.516 \\
99.193 / 0.807 \\
97.997 / 2.003 \\
95.967 / 4.033\end{array}$ & $\begin{array}{l}10760 \\
11721 \\
12303 \\
13723\end{array}$ & $\begin{array}{l}74.6 \pm 0.6 \\
81.1 \pm 0.7 \\
84.5 \pm 0.6 \\
93.3 \pm 0.7\end{array}$ \\
\hline $\mathrm{C}_{1} / \mathrm{C}_{3} / \mathrm{N}_{2}$ & $78.948 / 5.026 / 16.026$ & 13229 & $91.4 \pm 0.6$ \\
\hline $\mathrm{C}_{1} / \mathrm{iC}_{4}$ & $\begin{array}{l}99.405 / 0.595 \\
95.968 / 4.032 \\
93.187 / 6.813\end{array}$ & $\begin{array}{l}12383 \\
15329 \\
15456\end{array}$ & $\begin{array}{c}86.1 \pm 0.7 \\
103.3 \pm 0.7 \\
100.6 \pm 0.6\end{array}$ \\
\hline $\mathrm{C}_{1} / \mathrm{iC}_{4} / \mathrm{N}_{2}$ & $76.728 / 4.613 / 18.659$ & 13445 & $95.4 \pm 0.7$ \\
\hline $\mathrm{C}_{1} / \mathrm{nC}_{4}$ & $\begin{array}{l}99.481 / 0.519 \\
98.993 / 1.007 \\
97.774 / 2.226 \\
94.501 / 5.499\end{array}$ & $\begin{array}{c}8708 \\
9282 \\
11114 \\
13101\end{array}$ & $\begin{array}{l}60.0 \pm 0.6 \\
63.5 \pm 0.6 \\
74.9 \pm 0.8 \\
83.5 \pm 0.9\end{array}$ \\
\hline $\mathrm{C}_{1} / \mathrm{nC}_{4} / \mathrm{N}_{2}$ & $78.197 / 4.375 / 17.428$ & 13396 & $92.2 \pm 1.0$ \\
\hline
\end{tabular}

aUncertainty represented as expanded uncertainty $(U)$ at $95 \%$ level of confidence

With the exception of $\mathrm{nC}_{4}$ addition to $\mathrm{C}_{1}$, the previous figures reveal that the slope (Figure 5) and $\Delta H_{d}$ (Figure 6) are very sensitive towards composition. Both parameters increase sharply with $\mathrm{C}_{3} / \mathrm{iC}_{4}$ composition until subsequent composition increases result in diminishing returns. Only very small concentrations are therefore necessary for the system to favour the sll type hydrate. This is consistent with the early work performed by Deaton and Frost (1946) who found that 1 mol\% of $\mathrm{C}_{3}$ in $\mathrm{C}_{1}$ would produce sll hydrates.

Slopes and $\Delta H_{d}$ values were also computed for the mixtures where a $N_{2}$ diluent was introduced. One $\mathrm{N}_{2}$ mixture was tested and analysed for each of the hydrocarbon additives $\left(\mathrm{N}_{2}\right.$ concentration shown in Figure 2 - Figure 4). The previous figures include the calculated slope and $\Delta H_{d}$ values. The magnitude of the slope (Figure 5 ) is consistently less compared to a mixture with identical $\mathrm{C}_{3} / \mathrm{iC}_{4} / \mathrm{nC}_{4}$ composition as identified by the inserted trend-lines. $\mathrm{N}_{2}$ does not contribute to hydrate stability throughout the tested pressure/ $\mathrm{N}_{2}$ fugacity ranges (van Cleef \& Diepen, 1960) - rather it indirectly reduces hydrate stability by reducing the 
occupation of potential guests due to their reduced fugacity. For example, a $5 \mathrm{~mol}_{\%} \mathrm{C}_{3}$ (in $\mathrm{C}_{1}$ ) mixture has slope a greater than a $5.026 \mathrm{~mol} \%$ mixture $+16.026 \mathrm{~mol} \% \mathrm{~N}_{2}$ (in $\mathrm{C}_{1}$ ) as shown in Figure 5 of which can be explained by the reduced $C_{1}$ fugacity and therefore lower hydrate phase occupation. The opposite is generally true regarding $\Delta H_{d}-$ it is higher when $\mathrm{N}_{2}$ is included in the mixture. This is a consequence of $\mathrm{N}_{2}$ 's compressibility. The value of $\Delta H_{d}$ depends on $Z$, the compressibility of the gas mixture. As calculated by the Peng-Robinson (PR) equation, $\mathrm{N}_{2}$ has a higher $Z$ value than the other gas constituents, leading to a higher overall $Z$ for mixtures involving $\mathrm{N}_{2}$ (Peng \& Robinson, 1976). In accordance with Eq. 2, this corresponds to a higher $\Delta H_{d}$. Such an occurrence does not manifest for the case of $\mathrm{iC}_{4}$ mixtures. In this instance the decline in slope for the $4.613 \mathrm{~mol} \%+18.659 \mathrm{~mol} \% \mathrm{~N}_{2}$ mixture is too significant for $Z$ to counteract with respect to the predicted $\Delta H_{d}$ of a $4.613 \mathrm{~mol} \%$ mixture without $\mathrm{N}_{2}$ in Figure 6.

Interestingly, the addition of $\mathrm{nC}_{4}$ has little to no effect until its composition reaches approximately $0.5 \mathrm{~mol} \%$. This leads to the conclusion that $\mathrm{nC}_{4}$ is inert when $<0.5 \mathrm{~mol} \%$ and has no direct influence towards the hydrate phase. Beyond $0.5 \mathrm{~mol} \%$, a similar initial profile to $\mathrm{C}_{3}$ and $\mathrm{iC}_{4}$ exists where the Clausius-Clapeyron slope and $\Delta H_{d}$ is steeply inclined before flattening out. Of note is the steepness or sensitivity of the initial inclination of slope/ $\Delta H_{d}$. Observation leads to the conclusion that slope/ $\Delta H_{d}$ sensitivity, and therefore equilibria promotion, towards composition is ranked as $\mathrm{iC}_{4}>\mathrm{C}_{3}>\mathrm{nC}_{4}$. This is summarised by determining the gradient for the steep regions in Figure 5 and Figure 6, i.e. $d($ slope $) / d(m o l \%)$ and $\mathrm{d}\left(\Delta H_{d}\right) / \mathrm{d}(\mathrm{mol} \%)$ respectively.

\begin{tabular}{|l|ccc|}
\hline \multicolumn{5}{|c|}{ Table 6 - Equilibria Promotion Sensitivity } \\
\\
\hline Additive & $\begin{array}{c}\mathrm{d}(\text { slope }) / \mathrm{d}(\mathrm{mol} \%) \\
(\mathrm{K} / \mathrm{mol} \%)\end{array}$ & $\begin{array}{c}\mathrm{d}\left(\Delta H_{d}\right) / \mathrm{d}(\mathrm{mol} \%) \\
(\mathrm{kJ} / \mathrm{mol} . \mathrm{mol} \%)\end{array}$ & $\begin{array}{c}\text { Range } \\
(\mathrm{mol} \%)\end{array}$ \\
\hline $\mathrm{C}_{3}$ & $4232 \pm 36$ & $26.64 \pm 0.23$ & $0.0-0.5$ \\
$\mathrm{iC}_{4}$ & $6223 \pm 49$ & $43.50 \pm 0.34$ & $0.0-0.6$ \\
$\mathrm{nC}_{4}$ & $1808 \pm 20$ & $11.66 \pm 0.13$ & $0.5-2.2$ \\
\hline a Uncertainty represented as expanded uncertainty (U) at $95 \%$ level of confidence
\end{tabular}

The values provided in Table 6 are unique for each additive on the premise that $\mathrm{d}(\ln P) / \mathrm{d}(1 / T)$ and $\Delta H_{d}$ are reflective of said additive's ability to stabilise the large cavity of the sll lattice (Sloan \& Fleyfel, 1992); (Sloan \& Fleyfel, 1994). They represent the sensitivity of equilibria promotion via an increase in composition within the tabulated concentration range with 
regards to $\Delta H_{d}$ and the slope of the Clausius-Clapeyron equation. Provided that the slope $/ \Delta H_{d}$ is known for a particular composition, equilibria for compositions within the given range may be generated.

\subsubsection{Structure Transition}

In the previous section, Figure 5 and Figure 6 indicated that from $0.0-0.5 \mathrm{~mol}_{\%}, \mathrm{nC}_{4}$ had no obvious promoting effect towards the thermodynamic conditions of the resultant $\mathrm{C}_{1}-\mathrm{nC}_{4}$ hydrate equilibria. In identifying a similar phenomenon with the $\mathrm{C}_{1}-\mathrm{C}_{3} / \mathrm{iC}_{4}$, the vdWP model with the PR equation of state incorporated in Calsep's PVTsim software (ver. 20) was consulted. Unfortunately, the experimental equipment made available was not sufficient in accurately providing very low compositions without significant error associated with the desired low $\mathrm{C}_{3} / \mathrm{iC}_{4} / \mathrm{nC}_{4}$ concentrations. Using computed values of pressure and temperature for low additive compositions $(0.0-0.5 \mathrm{~mol} \%), \mathrm{d}(\ln P) / \mathrm{d}(1 / T)$ and $\Delta H_{d}$ were calculated. They are presented graphically in Figure 6, Figure 7 and Figure 8 respectively.

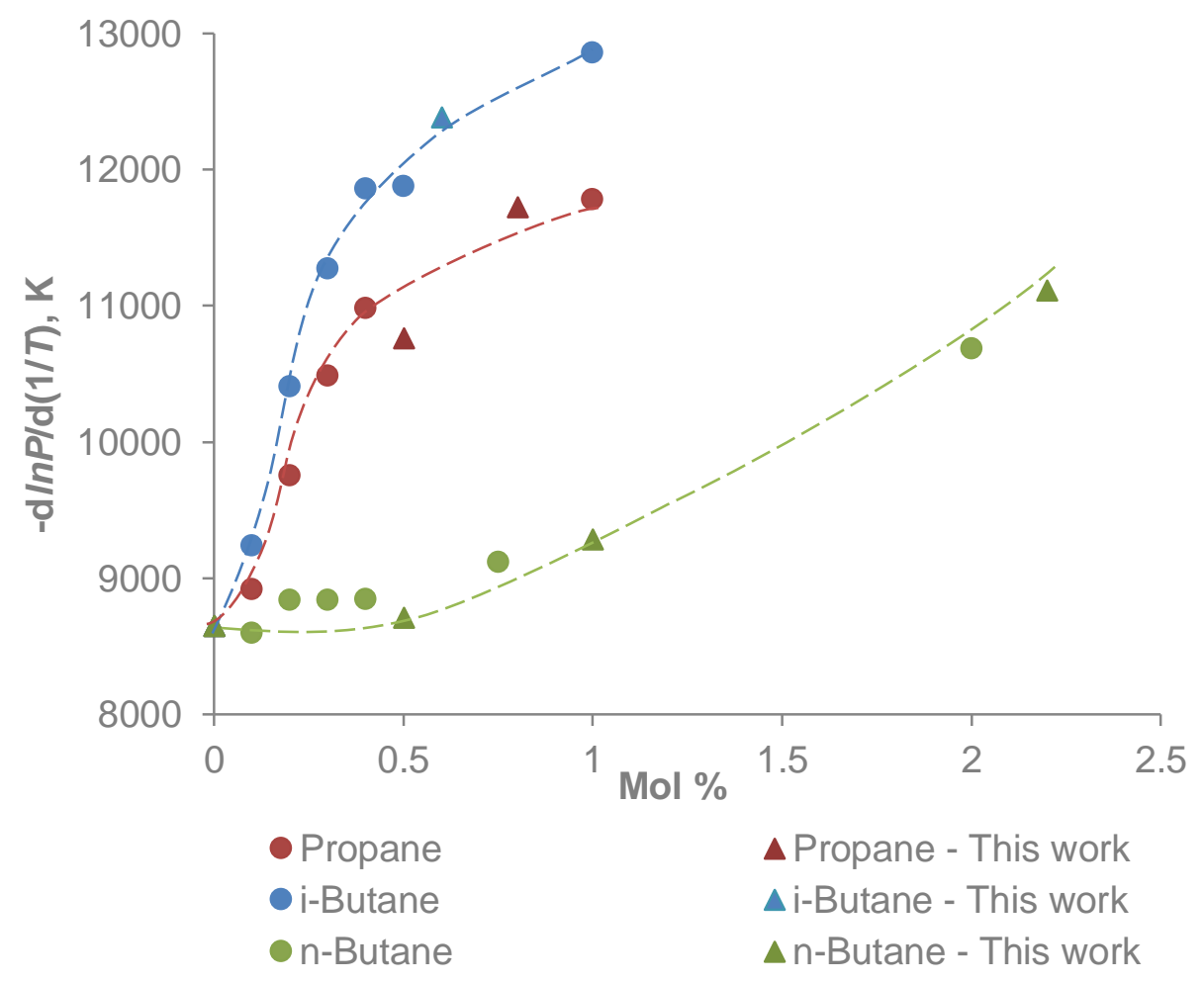

Figure $7-\mathrm{d}(\operatorname{In} P) / \mathrm{d}(1 / T)$ against Composition (0 - $2.2 \mathrm{~mol} \%)$ 


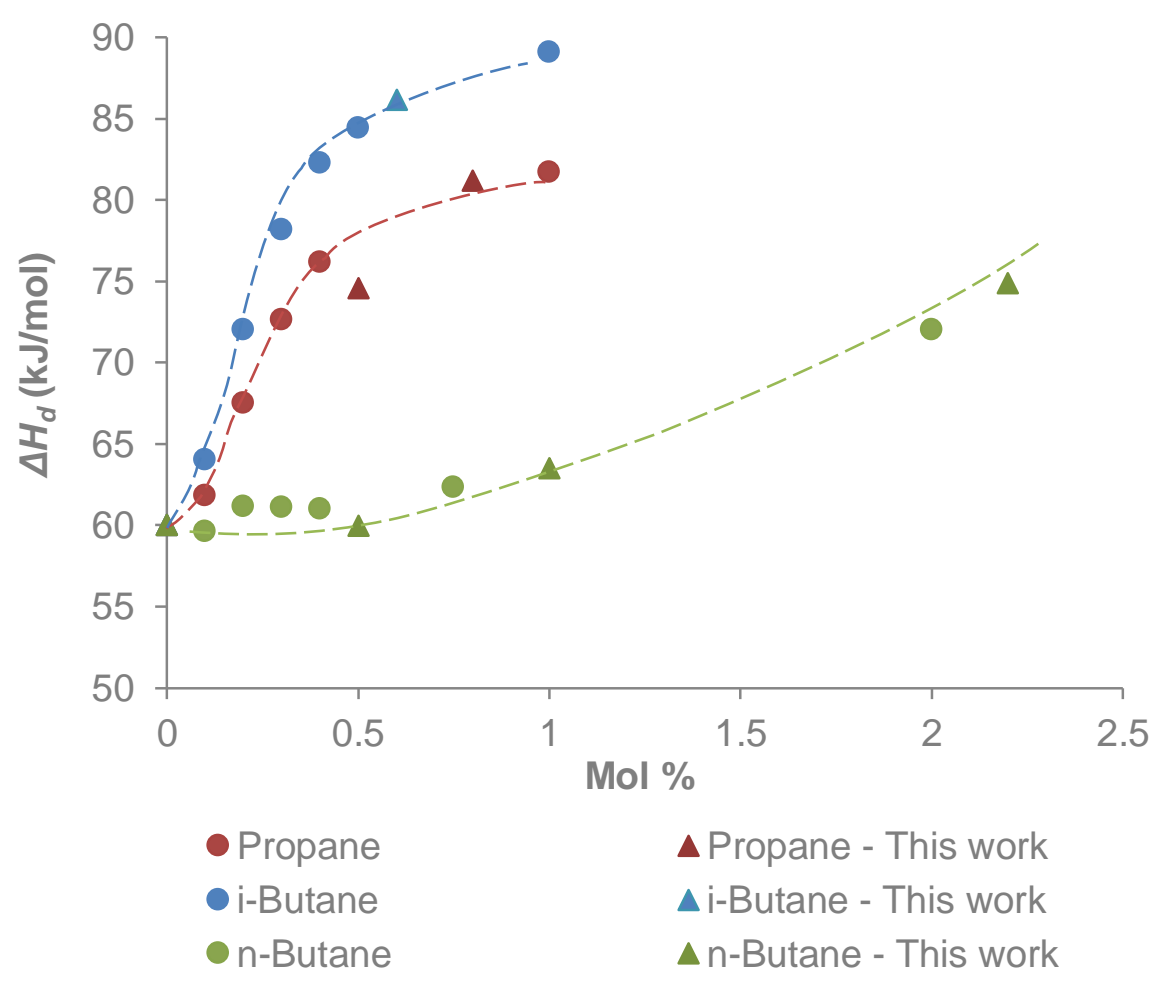

Figure $8-\Delta H_{d}$ against Composition (0 - $\left.2.2 \mathrm{~mol} \%\right)$

Figure 7 and Figure 8 are more resolved versions of Figure 5 and Figure 6 and attempt to establish the notion that there is a small period where a transition from sl to sll occurs - i.e., a flat region (or very low gradient) from $0.0-\mathrm{x}$ mol\% where $\mathrm{x}$ is specific to the $\mathrm{C}_{1}$ additive. The case with $\mathrm{nC}_{4}$ has already been made apparent and is seemingly inert from $0.0-0.5$ mol\%. A transition from sl to sll transpires from $0.5-0.75$ mol\% according to Figure 7 and Figure 8. At increments of $0.1 \mathrm{~mol} \%, \mathrm{C}_{3}$ and $\mathrm{iC}_{4}$ still do not appear to demonstrate insensitivity. This is consistent with the work of $\mathrm{Wu}$ and co-workers who noticed equilibria promotion for $0.23 \mathrm{~mol}_{\mathrm{i}} \mathrm{iC}_{4}$ in $\mathrm{C}_{1}$ relative to pure $\mathrm{C}_{1}$ hydrate $(\mathrm{Wu}$, et al., 1976). However, the gradient between increments $(0.0-0.1,0.1-0.2$ mol\% etc) is initially increasing up to approximately $0.3-0.5$ mol\% for both $\mathrm{C}_{3}$ and $\mathrm{iC}_{4}$, i.e. there is an inflection point. This may imply that the gradient is small enough at some region from $0.0-x$ mol\% that the addition of $\mathrm{C}_{3} / \mathrm{iC}_{4}$ does not influence the hydrate structure. For now, it can be presumed that the concentrations where the sl to sll transition occurs lies between $0.0-0.1 \mathrm{~mol} \%$ (Table 7). 


\begin{tabular}{|l|c|}
\hline \multicolumn{2}{|c|}{ Table 7 - Structure I to II Transition } \\
Composition \\
Hydrate System & Composition, mol\% \\
\hline $\mathrm{C}_{1}-\mathrm{C}_{3}$ & $0.0-0.1$ \\
$\mathrm{C}_{1}-\mathrm{iC}_{4}$ & $0.0-0.1$ \\
$\mathrm{C}_{1}-\mathrm{nC}_{4}$ & $0.5-0.75$ \\
\hline
\end{tabular}

It is reiterated that these arguments are based on supporting data provided by the vdWP model in PVTsim. The experimental data points fit well with those from the model and are consistent with the trends depicted in the preceding two figures, giving merit to the discussion. Given the agreement of the performed experimental work with the trends set by theoretical values, experimentation with compositions below $0.1 \mathrm{~mol} \%$ for $\mathrm{C}_{3} / \mathrm{iC}_{4}$ in $\mathrm{C}_{1}$ are warranted and will likely pin-point the composition range of $\mathrm{C}_{3} / \mathrm{iC}_{4}$ hydrate-inert behaviour. The presented findings, along with the promising aspect of further experimentation, are valuable to industry - particularly with regards to natural gas recovering and processing. Knowing the compositions where $\mathrm{C}_{3} / \mathrm{iC}_{4} / \mathrm{nC}_{4}$ (two of which provide significant hydrate stability with $C_{1}$ ) do not synergise with $C_{1}$ can be inherently advantageous. For instance, rather than separating these components entirely, they may remain in gas processing streams at small enough compositions where the hydrate formation conditions are still tolerable, thus reducing separating requirements. Although natural gas constitutes many more species than the rather simple mixtures used in this study, the majority of natural gases form sll given the favourability of the sll lattice when sll guests are present (Kini, et al., 2004); (Sloan \& Koh, 2008). Findings and discussions may therefore be extended to natural gas hydrates.

\section{Conclusion}

The extent of the hydrate-promoting behaviour of $\mathrm{C}_{3}, \mathrm{iC}_{4}$ and $\mathrm{nC}_{4}$ in $\mathrm{C}_{1}$ has been established by analysing their respective hydrate equilibrium profiles. The slope of the ClausiusClapeyron equation and $\Delta H_{d}$ have been used as a numerical indicator for their propensity to provide stability to the sll hydrate configuration. A trend between these quantities and the added hydrocarbon's concentration was established and this made it possible to illustrate the increasing structural stability of the sll hydrate with increased concentration. Analysing these results provided a concentration range $\left(0.0-0.5\right.$ mol\%) where $\mathrm{nC}_{4}$ was inert - it was concluded sll hydrates form at approximately $0.5-0.75$ mol\% for $\mathrm{C}_{1}-\mathrm{nC}_{4}$ hydrates. The sensitivity of hydrate equilibrium promotion with $\mathrm{C}_{3}$ and $\mathrm{iC}_{4}$ concentration increases was 
mostly apparent at small concentrations. With aid of the implemented vdWP model in PVTsim, the possibility of a small $\mathrm{C}_{3} / \mathrm{iC}_{4}$ inert range was implied $(0.0-0.1 \mathrm{~mol} \%)$.

Throughout the identified regions of high sensitivity, gradients of slope/ $\Delta H_{d}$ against concentration were calculated and are unique for each additive. Provided the slope $/ \Delta H_{d}$ for a particular set of equilibria at a composition within the specified range is known, equilibria for other concentrations can be generated. The value behind this is its application to further conformational investigation as well as to gas recovery and processing. Experimentally, the minute concentration range for $\mathrm{C}_{3}$ and $\mathrm{iC}_{4}$ hydrate-inertness in $\mathrm{C}_{1}$ requires confirmation. With this in mind, $\mathrm{C}_{3} / \mathrm{iC}_{4} / \mathrm{nC}_{4}$ may not be required to be separated completely from $\mathrm{C}_{1}$ for the purpose of ensuring no promotion of the equilibrium thermodynamic parameters.

\section{Acknowledgements}

The authors wish to thank Shell Australia for their support behind this project. Their financial and critical input has been invaluable. 


\section{References}

Adisasmito, S., Frank, R. \& Sloan, E., 1991. Hydrates of Carbon Dioxide and Methane Mixtures. Journal of Chemical Engineering Data, pp. 68-71.

Adisasmito, S. \& Sloan, E. D., 1992. Hydrates of Hydrocarbon Gases Containing Carbon Dioxide. Journal of Chemical Engineering Data, pp. 343-349.

Byk, S. \& Fomina, V., 1968. Gas Hydrates. Russian Chemical Reviews, pp. 469-91.

Cady, G. H., 1983. Composition of Gas Hydrates. Journal of Chemical Education, pp. 915918.

Christiansen, R. L. \& Sloan, E. D., 1994. Mechanisms and Kinetics of Hydrate Formation. Annals New York Academy of Sciences, pp. 283-305.

Claussen, W. \& Frost, E., 1951. Suggested Structures of Water on Inert Gas Hydrates. Journal of Chemical Physics, pp. 259-60.

Deaton, W. \& Frost, E., 1946. Gas Hydrates and Their Relation to the Operation of Natural Gas Pipelines, s.I.: U.S. Bureau of Mines.

Gayet, P. et al., 2005. Experimental Determination of Methane Hydrate Dissociation Curve up to $55 \mathrm{MPa}$ by Using a Small Amount of Surfactant as Hydrate Promoter. Chemical Engineering Science, pp. 5751-58.

ISO, 2008. Evaluation of Measurement Data — Guide to the Expression of Uncertainty in Measurement. s.I.:JCGM.

Jhaveri, J. \& Robinson, D., 1965. Hydrates in the Methane-Nitrogen System. The Canadian Journal of Chemical Engineering, pp. 75-8.

Kini, R., Dec, S. \& Sloan, E., 2004. Methane + Propane Structure II Hydrate Formation Kinetics. Journal of Physical Chemistry, pp. 9550-56.

Lederhos, J. P., Christiansen, L. \& Sloan, E. D., 1993. A First Order Method of Hydrate Equilibrium Estimation and its Use With New Structures. Fluid Phase Equilibria, pp. 83-445.

Marshall, D., Saito, S. \& Kobayashi, R., 1964. Hydrates at High Pressures: Part 1. MethaneWater, Argon-Water and Nitrogen-Water Systems. AIChE Journal, Volume 10, pp. 202-05.

Mcleod, H. \& Campbell, J., 1961. Natural Gas Hydrates at Pressures to 10,000 psia. Journal of Petroleum Technology, pp. 590-94.

Musaev, R., 1966. Candidate's Thesis, Moscow: All-Union Scientific Research Institute for Gas.

$\mathrm{Ng}, \mathrm{H} .-\mathrm{J}$. \& Robinson, D., 1976. The Role of n-Butane in Hydrate Formation. AlChE Journal, pp. 656-61.

Parrish, W. \& Prausnitz, J., 1972. Dissociation Pressures of Gas Hydrates Formed by Gas Mixtures. Ind. Eng. Chem. Process Des. Delep., pp. 26-34. 
Peng, D.-Y. \& Robinson, D., 1976. A New Two-Constant Equation of State. Industrial and Engineering Chemistry: Fundamentals, pp. 59-64.

Schicks, J. et al., 2006. Phase Transitions in Mixed Gas Hydrates: Experimental Observations versus Calculated Data. The Journal of Physical Chemistry, pp. 11468-74.

Shin, H. et al., 2009. Thermodynamic Stability, Spectroscopic Identification and Cage Occupation of Binary CO2 Clathrate Hydrates. Chemical Engineering Science, pp. 51255130.

Sloan, E. \& Fleyfel, F., 1992. Hydrate Dissociation Enthalpy and Guest Size. Fluid Phase Equilibria, pp. 123-140.

Sloan, E. \& Fleyfel, F., 1994. Reply to "comments on: hydrate dissociation enthalpy and guest size". Fluid Phase Equilibria, pp. 233-235.

Sloan, E. \& Koh, C., 2008. Clathrate of Natural Gas Hydrates, Third Edition. s.I.:Taylor \& Francis Group.

Smith, C., Barifcani, A. \& Pack, D., 2015. Gas Hydrate Formation And Dissociation Numerical Modelling with Nitrogen and Carbon Dioxide. Journal of Natural Gas Science and Engineering, Vol. 27, pp. 1118-28.

Smith, C., Barifcani, A. \& Pack, D., 2016. Helium Substitution of Natural Gas Hydrocarbons in the Analysis of their Hydrate. Journal of Natural Gas Science and Engineering, pp. 12931300 .

Song, K. \& Kobayashi, R., 1982. Measurement and Interpretation of the Water Content of a Methane-Propane Mixture in the Gaseous State in Equilibrium with Hydrate. Industrial \& Engineering Chemistry Fundamentals, pp. 391-95.

Stackelber, M. \& Muller, H., 1951. On the Structure of Gas Hydrates. Journal of Chemical Physics, pp. 1319-20.

Tohidi, B. et al., 2000. Improving the Accuracy of Gas Hydrate Dissociation Point Measurements. Annals New York Academy of Sciences, pp. 924-931.

van Cleef, A. \& Diepen, G., 1960. Gas Hydrates of Nitrogen and Oxygen. Recueil des Travaux Chimiques des Pays-Bas, pp. 582-86.

van der Waals, J. \& Platteeuw, J., 1959. Clathrate Solutions. Advances in Chemical Physics, pp. 1-59.

Wu, B., Robinson, D. \& Ng, H., 1976. Three- and Four-Phase Hydrate Forming Conditions in Methane + Isobutane + Water. The Journal of Chemical Thermodynamics, pp. 461-69. 